\title{
Vitamin D represses rhinovirus replication in cystic fibrosis cells by inducing LL-37
}

\author{
Aline Schögler ${ }^{1,2,3}$, Ricardo J. Muster ${ }^{1,2}$, Elisabeth Kieninger ${ }^{1,4}$, \\ Carmen Casaulta ${ }^{1}$, Caroline Tapparel ${ }^{5}$, Andreas Jung ${ }^{6}$, Alexander Moeller ${ }^{6}$, \\ Thomas Geiser ${ }^{2,7}$, Nicolas Regamey ${ }^{2,8}$ and Marco P. Alves ${ }^{1,2}$
}

\begin{abstract}
Affiliations: 'Division of Paediatric Respiratory Medicine, University Children's Hospital, Bern, Switzerland. ${ }^{2}$ Dept of Clinical Research, University of Bern, Bern, Switzerland. ${ }^{3}$ Graduate School for Cellular and Biomedical Sciences, University of Bern, Bern, Switzerland. "University Children's Hospital Basel, UKBB, Basel, Switzerland. ${ }^{5}$ Laboratory of Virology, Division of Infectious Diseases and Division of Laboratory Medicine, University of Geneva Hospitals and Faculty of Medicine, University of Geneva, Geneva, Switzerland. ${ }^{6}$ Division of Respiratory Medicine, University Children's Hospital, Zürich, Switzerland. ${ }^{7}$ Dept of Pulmonary Medicine, University Hospital Bern, Bern, Switzerland. ${ }^{8}$ Division of Paediatric Respiratory Medicine, Lucerne Children's Hospital, Lucerne, Switzerland.
\end{abstract}

Correspondence: Marco P. Alves, Dept of Clinical Research, University of Bern, 3008 Bern, Switzerland. E-mail: marco.alvesdadkf.unibe.ch

ABSTRACT Vitamin D has immunomodulatory properties in the defence against pathogens. Its insufficiency is a widespread feature of cystic fibrosis (CF) patients, which are repeatedly suffering from rhinovirus (RV)-induced pulmonary exacerbations.

To investigate whether vitamin D has antiviral activity, primary bronchial epithelial cells from CF children were pre-treated with vitamin D and infected with RV16. Antiviral and anti-inflammatory activity of vitamin D was assessed. RV and LL-37 levels were measured in bronchoalveolar lavage (BAL) of CF children infected with RV.

Vitamin D reduced RV16 load in a dose-dependent manner in CF cells $\left(10^{-7} \mathrm{M}, \mathrm{p}<0.01\right)$. The antiviral response mediated by interferons remained unchanged by vitamin $\mathrm{D}$ in CF cells. Vitamin D did not exert anti-inflammatory properties in RV-infected CF cells. Vitamin D increased the expression of the antimicrobial peptide LL-37 up to 17.4-fold $(\mathrm{p}<0.05)$. Addition of exogenous LL-37 decreased viral replication by 4.4 -fold in CF cells $(\mathrm{p}<0.05)$. An inverse correlation between viral load and LL-37 levels in CF BAL $(\mathrm{r}=-0.48, \mathrm{p}<0.05)$ was observed.

RV replication in primary CF bronchial cells was reduced by vitamin D through the induction of LL-37. Clinical studies are needed to determine the importance of an adequate control of vitamin $\mathrm{D}$ for prevention of virus-induced pulmonary CF exacerbations.

@ERSpublications

Rhinovirus replication is decreased in CF cells by vitamin D through the induction of the antimicrobial peptide LL-37 http://ow.ly/Snsyo

Received: April 282015 | Accepted after revision: Aug 242015 | First published online: Nov 192015

Support statement: Funding was provided by Mukoviszidose eV.

Conflict of interest: None declared.

Copyright OERS 2016 


\section{Introduction}

Cystic fibrosis (CF) patients experience acute episodes of virus-induced pulmonary exacerbations, which have a significant clinical impact on CF lung disease [1-4]. Rhinovirus (RV) accounts for the vast majority of virus-associated pulmonary CF exacerbations [5-7]. To date, therapeutic options to prevent CF pulmonary deteriorations induced by viruses are rare. Recently the role of vitamin $\mathrm{D}$ in the innate immune defence towards pathogens has become increasingly recognised $[8,9]$. Vitamin D is a steroid hormone classically linked to bone and calcium metabolism and supposedly involved in the regulation of innate immune responses. Despite routine oral supplementation with vitamin $\mathrm{D}$, more than $90 \%$ of $\mathrm{CF}$ patients are presented with insufficient serum vitamin $D$ levels $\left(<30 \mathrm{ng} \cdot \mathrm{mL}^{-1}\right)[10,11]$. Epidemiological studies show an inverse association of vitamin D levels in the serum and infections of the upper [12, 13] and lower $[14,15]$ respiratory tract. Moreover, vitamin D status and metabolism have been reported to modulate virus infections such as respiratory syncytial virus (RSV) $[16,17]$ and influenza A virus (IAV) $[18,19]$ infection, demonstrating a central role of this molecule in the innate immune response to respiratory viruses. These observations and the fact that CF patients are often presented with insufficient vitamin D levels point to the potential role of vitamin D regarding the antiviral response in CF patients. We therefore hypothesised that vitamin D has antiviral activity in CF airway cells. We used an in vitro model based on RV-infected primary bronchial epithelial cells isolated from children with CF to evaluate the antiviral properties of vitamin $\mathrm{D}$.

\section{Material and methods}

\section{Study patients}

Primary bronchial epithelial cells of children with CF and healthy volunteers at a median (range) of 5.5 (1.1-16.1) years were collected at the University Hospitals of Bern and Zürich (Switzerland). 17 CF and 10 control cell cultures have been successfully established. The clinical characteristics of the study participants are shown in tables 1 and 2. Data of cells of CF patients 1-11, which have been recruited for this study, were published previously [21]. CF patients $12-17$ were additionally recruited to perform the recombinant LL-37 treatment experiment only. Exclusion criteria were previously defined as bleeding tendency, therapy with anticoagulants and/or immunosuppressive agents, steroid use within the past three months and atopy (the two latter for controls only). Written informed consent was obtained from all study participants and/ or caregivers and the study was approved by the ethics committees of the Canton of Bern and Zürich.

\section{Cell culture and rhinovirus propagation}

Submerged primary CF and control bronchial epithelial cells were obtained and grown in bronchial epithelial growth medium (Lonza, Switzerland) as previously described [21]. Major group RV16 stock from species A (American Type Culture Collection, Manassas, VA, USA) was grown and titrated on Ohio-HeLa cells (European Collection of Cell Cultures, Salisbury, UK) at $2.5 \times 10^{7} \mathrm{TCID}_{0}-\mathrm{mL}^{-1}$ (median tissue culture infective dose) as previously described [22].

\section{Vitamin D3 treatment and rhinovirus infection}

At passage two, primary bronchial cells were pre-treated with active vitamin D3 $\left(1,25-(\mathrm{OH})_{2} \mathrm{D}_{3}\right.$; Sigma-Aldrich, St. Louis, MO, USA) at $10^{-9} \mathrm{M}, 10^{-8} \mathrm{M}$ or $10^{-7} \mathrm{M}$ and placed in bronchial epithelial basal medium (BEBM; Lonza, Switzerland) without supplementation for $24 \mathrm{~h}$. $96 \%$ of ethanol was used to

\section{TABLE 1 Demographic and clinical characteristics of study controls}

\begin{tabular}{lcccc} 
Subjects & Sex & Age years & Atopy $^{\#}$ & Steroid use $^{\boldsymbol{\pi}}$ \\
\hline $\mathbf{1}$ & $\mathrm{M}$ & 7.6 & No & No \\
$\mathbf{2}$ & $\mathrm{M}$ & 12 & No & No \\
$\mathbf{3}$ & $\mathrm{F}$ & 14.8 & No & No \\
$\mathbf{4}$ & $\mathrm{M}$ & 4.2 & No & No \\
$\mathbf{5}$ & $\mathrm{M}$ & 1.7 & No & No \\
$\mathbf{6}$ & $\mathrm{M}$ & 16.2 & No & No \\
$\mathbf{7}$ & $\mathrm{F}$ & 13.3 & No & No \\
$\mathbf{8}$ & $\mathrm{M}$ & 1.4 & No & No \\
$\mathbf{9}$ & $\mathrm{M}$ & 5.5 & No & No \\
$\mathbf{1 0}$ & $\mathrm{F}$ & 14.2 & &
\end{tabular}

M: male; F: female. " : defined as positive history of hay fever, eczema or asthma. ": defined as any treatment with systemic, inhaled or nasal steroids within the past 3 months. 
TABLE 2 Demographic and clinical characteristics of study cystic fibrosis patients

\begin{tabular}{|c|c|c|c|c|c|c|c|c|c|c|}
\hline Patient & Sex & $\begin{array}{l}\text { Age } \\
\text { years }\end{array}$ & Atopy ${ }^{\#}$ & $\begin{array}{l}\text { Steroid } \\
\text { use }\end{array}$ & $\begin{array}{l}\text { FEV } 1 \\
\%\end{array}$ & Genotype & $\begin{array}{l}\text { Vitamin D } \\
\text { supplementation } \\
\text { units-day }{ }^{-1}\end{array}$ & $\begin{array}{c}\text { Under } \\
\text { exacerbation }{ }^{+}\end{array}$ & Pathogens ${ }^{\S}$ & $\begin{array}{l}\text { ABPA } \\
\text { history }\end{array}$ \\
\hline 2 & M & 3.8 & No & No & 108 & F508del/F508del & 800 & No & $\begin{array}{l}\text { S. aureus, } \\
\text { S. pneumoniae, } \\
\text { H. influenzae }\end{array}$ & No \\
\hline 4 & $\mathrm{~F}$ & 11 & Yes & No & 67 & G542X/2708del13 & 800 & No & $\begin{array}{l}\text { S. aureus, } \\
\text { A. fumigatus }\end{array}$ & Yes \\
\hline 5 & M & 8.7 & Yes & Inhaled & 106 & F508del/F508del & 800 & No & S. aureus & No \\
\hline 6 & M & 2.6 & No & Inhaled & ND & F508del/F508del & 800 & No & $\begin{array}{l}\text { P. aeruginosa, } \\
\text { Penicillium spp. }\end{array}$ & No \\
\hline 10 & M & 6.2 & No & No & 127 & F508del/F508del & 1200 & No & None & No \\
\hline 11 & M & 10.9 & No & No & 62 & No mutation found & None & No & None & No \\
\hline 12 & M & 3.1 & No & No & ND & F508del/F508del & 1000 & Yes & $\begin{array}{c}\text { S. aureus, } \\
\text { H. influenzae }\end{array}$ & No \\
\hline 13 & $\mathrm{~F}$ & 4.8 & No & Nasal & 139 & F508del/F508del & 1600 & No & $\begin{array}{l}\text { S. aureus, } \\
\text { H. influenzae }\end{array}$ & No \\
\hline 14 & $\mathrm{~F}$ & 2.6 & No & No & ND & F508del/F508del & 1800 & No & $\begin{array}{l}\text { P. aeruginosa, } \\
\text { S. aureus, } \\
\text { H. influenzae }\end{array}$ & No \\
\hline 15 & M & 3.0 & No & No & ND & F508del/F508del & 1200 & No & $\begin{array}{l}\text { S. aureus, } \\
\text { H. influenzae }\end{array}$ & No \\
\hline
\end{tabular}

M: male; F: female. FEV1: forced expiratory volume in $1 \mathrm{~s}$; ABPA: Allergic bronchopulmonary aspergillosis; ND: not determined; S. aureus: Staphylococcus aureus; H. influenzae: Haemophilus influenzae; S. pneumoniae: Streptococcus pneumoniae; P. aeruginosa: Pseudomonas aeruginosa; A. fumigatus: Aspergillus fumigatus; M. catarrhalis: Moraxella catarrhalis. " : defined as positive history of hay fever, eczema or asthma. ": defined as any treatment with systemic, inhaled or nasal steroids within the past 3 months; ${ }^{+}$: as defined by [20]; ${ }^{\S}$ : present in bronchoalveolar lavage fluid at time of brushing.

reconstitute active vitamin D3 to a stock solution of $10^{-4} \mathrm{M}$. Vitamin D was then further diluted in BEBM to the desired concentration giving a final ethanol concentration of $0.1 \%$ for $10^{-7} \mathrm{M}, 0.01 \%$ for $10^{-8} \mathrm{M}$ and $0.001 \%$ for $10^{-9} \mathrm{M}$ vitamin D. $10^{-7} \mathrm{M}$ of vitamin D equals $40 \mathrm{ng} \cdot \mathrm{mL}^{-1}$, which is a typical concentration of vitamin $\mathrm{D}$ in human serum; thus, the dosages used for experimentation were in the physiological range [8]. Using a multiplicity of infection of $4,80-90 \%$ confluent cells were infected with RV16 for $1 \mathrm{~h}$. $24 \mathrm{~h}$ post-infection, cell lysates and supernatants were collected and stored at $-80^{\circ} \mathrm{C}$ until further analysis.

\section{RNA extraction and cDNA synthesis}

Total RNA isolation was performed by using the NucleoSpin RNA kit (Macherey-Nagel, Switzerland) according to the manufacturer's manual. cDNA was synthesised from $200 \mu \mathrm{g}$ of total RNA by using the Omniscript RT Kit (Qiagen, Basel, Switzerland).

\section{$R T-P C R$}

Quantitative RT-PCR was performed by using $2 \mu \mathrm{L}$ of cDNA and $18 \mu \mathrm{L}$ of Taqman Fast universal PCR master mix (Thermo Fisher Scientific, Waltham, MA, USA) containing specific primers $(20 \mu \mathrm{M})$ and probes $(5 \mu \mathrm{M}$ ) for $18 \mathrm{~S}$ [21], RV (intracellular viral RNA) [21], interferon (IFN) $\lambda 2 / 3$ [21], viperin (virus inhibitory protein, endoplasmic reticulum-associated, interferon-inducible), Toll-like receptor 3 (TLR3) 
[21], retinoic acid inducible gene I (RIG-I) [21], melanoma differentiation-associated protein 5 (MDA5) [21], $\beta$-defensin 2 (forward primer: 5'-ACAAATTGGCACCTGTGGTCT-3'; reverse primer: 5'-GCAGCTTCTTGGCCTCTC-3'; probe: 5'-FAM-CCTGGAACAAAATGCTGCAAAAGCC-TAMRA-3') [23] and LL-37 (forward primer: 5'-CATCGATTTCTTCCCTGTGAA-3'; reverse primer: 5' -TCTTGGAGCTTATTAAAGGCATTC-3'; probe 5'-FAM-ACAAGAGCAAGGCCGTGGAGCA-TAMRA-3') [24]. PCR reactions were carried out on a 7500 fast Real-Time PCR System (Thermo Fisher Scientific). The $\Delta \Delta C T$ method was used to quantify the mRNA expression levels of endogenous genes, which were normalised to the housekeeping gene 18S rRNA. Viral RNA copies numbers were obtained through the generation of a standard curve obtained with serial dilutions of a plasmid containing RV cDNA.

ELISA

Protein levels of interleukin (IL)- 8 and IL-6 were measured in cell culture supernatants of vitamin D treated $\left(10^{-8} \mathrm{M}\right.$ and $\left.10^{-7} \mathrm{M}\right)$ and untreated CF cells by commercially available ELISA kits for human IL-8 and IL-6 (both R\&D Systems, Abingdon, UK).

\section{Recombinant LL-37 treatment}

Primary bronchial CF cells were placed in multi-well plates at passage two and grown in BEBM for $24 \mathrm{~h}$. Cells from CF patients 12-17 were infected with RV16 and subsequently post-treated with $20 \mu \mathrm{g} \cdot \mathrm{mL}^{-1}$ of recombinant LL-37 (Hycult Biotech, Plymouth Meeting, PA, USA) in BEBM for $24 \mathrm{~h}$. This concentration was chosen based on available literature [25] and preliminary experiments using different concentrations (1, 4 and $\left.20 \mu \mathrm{g} \cdot \mathrm{mL}^{-1}\right)$ (data not shown).

\section{Bronchoalveolar lavage}

$\mathrm{RV}$-positive bronchoalveolar lavage (BAL) samples of CF children were collected as previously described [20]. Clinical characteristics of study participants and measurement of RV load were derived from a previous study [20]. LL-37 protein levels were assessed in BALs using an ELISA kit for human LL-37 (Hycult Biotech, US) according to the manufacturer's manual.

\section{Statistical analysis}

Data are presented as median unless otherwise stated. Non-parametric, paired Wilcoxon tests were applied to determine differences between two groups. Correlation was tested using the Spearman rank correlation test. GraphPad Prism 5 software (GraphPad Software Inc., US) was used to perform statistical analysis. A p-value $<0.05$ was considered statistically significant.

\section{Results \\ Viral replication is repressed by vitamin D in CF bronchial epithelial cells in a dose-dependent manner}

To determine the effect of vitamin D on viral replication, primary CF bronchial cells pre-treated with vitamin D were infected with RV16 and viral replication was assessed. We found that treatment of CF cells with $10^{-7} \mathrm{M}$ of vitamin $\mathrm{D}$ significantly reduced virus replication by two-fold ( $\mathrm{p}=0.001$; figure 1 ), whereas virus replication was not repressed by treatment with $10^{-9} \mathrm{M}$ or $10^{-8} \mathrm{M}$ of vitamin $\mathrm{D}$ in CF cells compared to untreated cells (figure 1). Decreased virus replication was not due to vitamin D-induced cell death (data not shown).

\section{Vitamin $D$ does not stimulate an antiviral response mediated by the interferon pathway in CF} bronchial epithelial cells

The classical antiviral response elicited by airway epithelial cells is mediated through the IFN pathway. Recently it has been shown that the IFN pathway can be modulated by vitamin $\mathrm{D}$ through a synergistic manner with TLR pathway activation $[8,26]$. Thus, to investigate possible underlying antiviral mechanisms of vitamin $\mathrm{D}$, the expression of IFN- $\lambda 2 / 3$, a typical IFN produced by the airway epithelium upon infection, and of the prototypical IFN-stimulated gene (ISG) viperin were evaluated in RV-infected CF cells treated or not treated with $10^{-9} \mathrm{M}$ to $10^{-7} \mathrm{M}$ of vitamin $\mathrm{D}$. We observed that neither the expression of IFN $-\lambda 2 / 3$ nor the expression of viperin was induced by vitamin $\mathrm{D}$ treatment in infected $\mathrm{CF}$ cells compared with untreated cells (figure $2 \mathrm{a}$ and $\mathrm{b}$ ). To confirm that the IFN pathway was not involved in the antiviral activity of vitamin D in CF cells, we investigated further the expression of the pattern recognition receptors (PRRs) TLR3, RIG-I and MDA5 by vitamin D treatment in RV-infected CF cells. RVs are recognised in a coordinated manner by these three PRRs in airway epithelial cells [27] leading to downstream induction of IFNs. In accordance with IFN- $\lambda 2 / 3$ and viperin data, the assessed PRRs expressions were not modified by vitamin D treatment in RV-infected CF cells compared with untreated cells (figure $2 \mathrm{c}-\mathrm{e}$ ). 


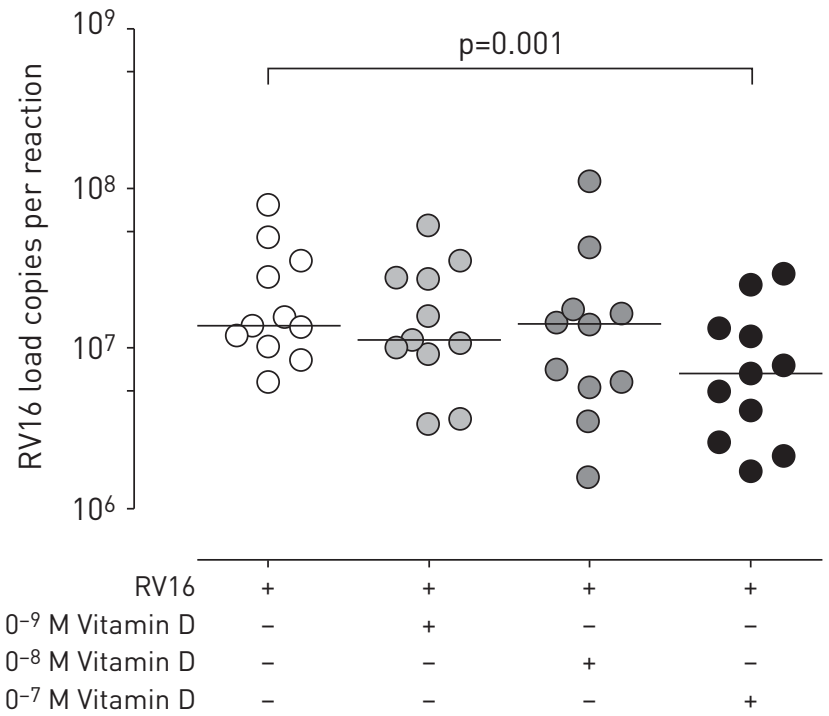

FIGURE 1 Rhinovirus (RV) load is repressed by vitamin D treatment in primary cystic fibrosis bronchial epithelial cells in a dose-dependent manner. Intracellular viral RNA with or without $24 \mathrm{~h}$ pre-treatment with vitamin D $\left(10^{-9} \mathrm{M}, 10^{-8} \mathrm{M}\right.$ and $\left.10^{-7} \mathrm{M}\right)$ was measured at $24 \mathrm{~h}$ post-RV16 infection by quantitative RT-PCR in primary cystic fibrosis bronchial epithelial cells. Data are presented as median of 11 independent experiments. Statistical analysis was done with the paired non-parametric Wilcoxon rank test.

\section{Pro-inflammatory cytokine secretion upon virus infection is not reduced by vitamin $D$ in CF} bronchial epithelial cells

CF lung disease is characterised by a deregulated inflammatory response with increased secretion of inflammatory cytokines such as IL-8 and IL-6 at baseline condition and upon virus infection [28, 29]. Also, vitamin D has been reported to have anti-inflammatory effects in airway epithelial cells $[4,30]$. Thus, we studied whether vitamin D treatment reduced RV-induced cytokine production in CF cells. We found that vitamin D treatment did not decrease RV-induced IL-8 and IL-6 secretion in CF cells compared with untreated cells (figure 3).

\section{LL-37 is induced by vitamin D treatment in RV-infected CF bronchial epithelial cells}

Antimicrobial peptides (AMPs) including $\beta$-defensin and LL-37 contribute to an elaborate innate immune response of airway epithelial cells to prevent microbial infections [31, 32]. As LL-37 and $\beta$-defensin are known to be induced by vitamin D in healthy and CF airway epithelial cells $[33,34]$, we investigated the expression of $\beta$-defensin and LL-37 by vitamin D treatment in RV-infected CF cells. We found that $\beta$-defensin expression was not increased in vitamin D-treated CF cells compared with untreated cells (figure 4a). However, the expression of LL-37 was amplified in a concentration-dependent manner by vitamin D in infected CF cells compared with untreated cells, reaching a significant 17.4 -fold induction by $10^{-7} \mathrm{M}$ vitamin $\mathrm{D}(\mathrm{p}=0.04$; figure $4 \mathrm{~b})$.

\section{Recombinant LL-37 treatment reduces RV replication in CF bronchial epithelial cells}

LL-37 has potent antiviral activity against several viruses such as RSV and IAV [35]. Thus, to evaluate whether LL-37 production is associated with the antiviral activities of vitamin D, viral replication upon recombinant LL-37 treatment was assessed in CF cells. We observed that RV replication was significantly decreased 4.4-fold in CF cells treated with LL-37 compared to untreated cells ( $p=0.03$; figure 5).

\section{LL-37 level is inversely associated with RV load in BAL of CF patients}

In order to confirm our in vitro observation in vivo, we measured vitamin D levels in BAL of RV-infected CF children [20]. Vitamin D levels in CF BAL were found to be undetectable as assessed by ELISA (data not shown). Therefore, we measured LL-37 protein levels in RV-infected CF children BAL and found a significant inverse correlation between RV load and LL-37 levels ( $r=-0.48 ; \mathrm{p}=0.03$; figure 6).

Vitamin D has antiviral properties in healthy bronchial epithelial cells

Since suboptimal serum vitamin D status $\left(<30 \mathrm{ng} \cdot \mathrm{mL}^{-1}\right)$ is also common in healthy children (40\%) [36], we assessed virus replication in vitamin $\mathrm{D}$ treated and untreated control cells. We found a 1.7 -fold reduced virus replication in control cells treated with $10^{-8} \mathrm{M}$ of vitamin $\mathrm{D}(\mathrm{p}=0.01)$ and a 2.8 -fold decrease in 


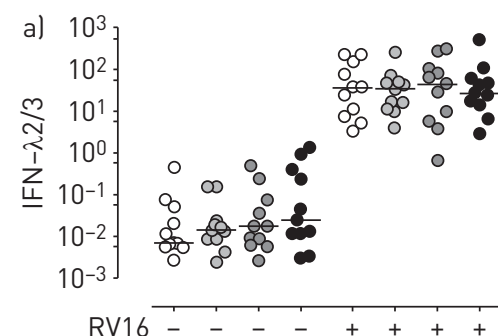

10-9 M Vitamin D - + - - + + 10-8 M Vitamin D - - + - - + +

$10^{-7} \mathrm{M}$ Vitamin D - $-\quad+\ldots+$
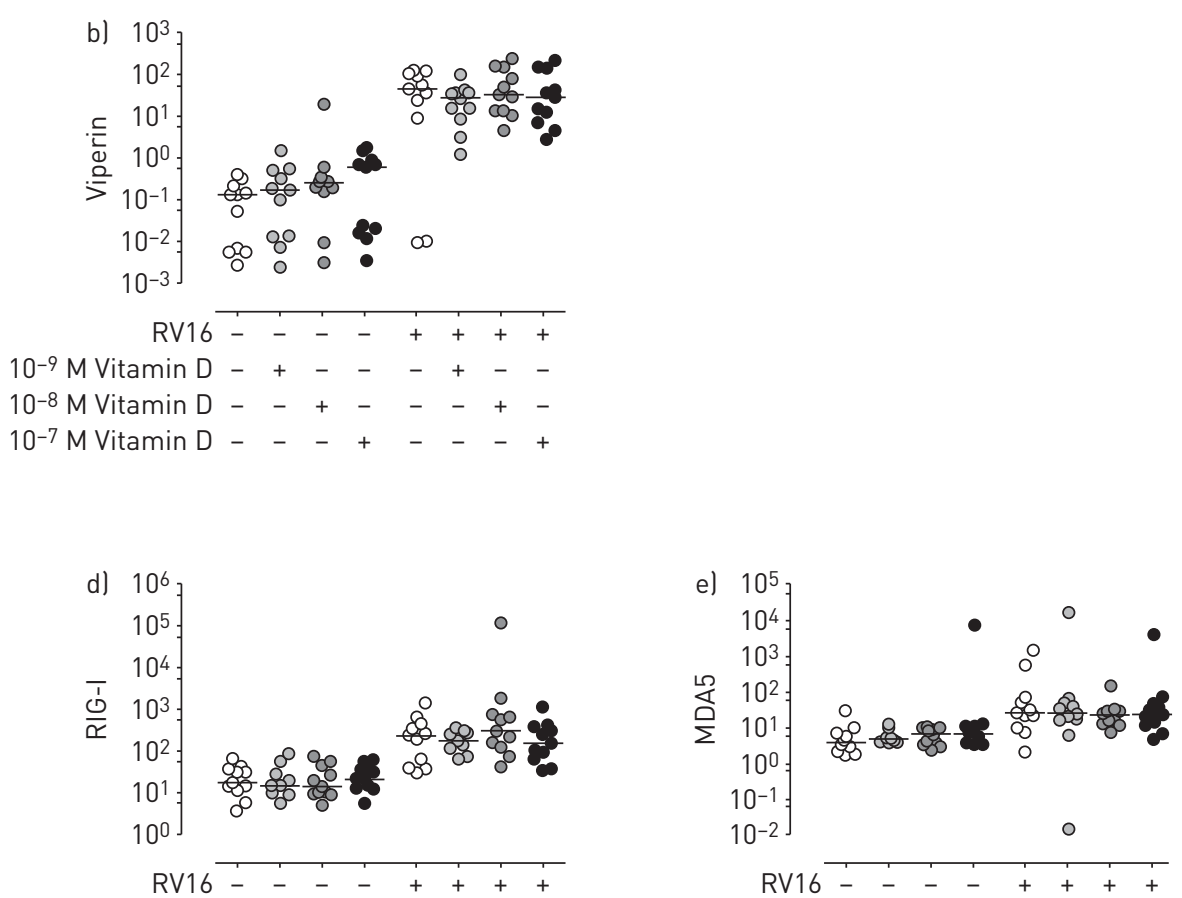

10-9 M Vitamin D - + - - - + -

10-9 M Vitamin D - + - - - + - -

10-8 M Vitamin D - _ + - _ + -

$10^{-7}$ M Vitamin D - $-+\ldots+$

FIGURE 2 Interferon (IFN)- $\lambda 2 / 3$, viperin and pattern recognition receptors (PRRs) expressions, normalised to $10^{5} 18 \mathrm{~S}$ mRNA, are not modulated by vitamin $\mathrm{D}$ treatment in rhinovirus (RV)-infected primary cystic fibrosis (CF) bronchial epithelial cells. a) IFN- $\lambda 2 / 3$ and b) viperin mRNA expression was assessed at $24 \mathrm{~h}$ post RV16 infection by quantitative RT-PCR with or without $24 \mathrm{~h}$ pre-treatment with vitamin $\mathrm{D}\left(10^{-9} \mathrm{M}, 10^{-8} \mathrm{M}\right.$ and $\left.10^{-7} \mathrm{M}\right)$ in primary CF bronchial epithelial cells. mRNA levels of the PRRs, c) Toll-like receptor 3 (TLR3), d) retinoic acid inducible gene I (RIG-I), and e) melanoma differentiation-associated protein 5 (MDA5) were measured at $24 \mathrm{~h}$ after RV16 infection by RT-PCR in primary CF bronchial epithelial cells treated or not treated with vitamin $\mathrm{D}\left(10^{-9} \mathrm{M}, 10^{-8} \mathrm{M}\right.$ and $\left.10^{-7} \mathrm{M}\right)$ for $24 \mathrm{~h}$. Data are presented as median of 11 independent experiments. Statistical analysis was done with the paired non-parametric Wilcoxon rank test.

virus replication by $10^{-7} \mathrm{M}$ vitamin $\mathrm{D}(\mathrm{p}=0.002)$ in control cells compared to untreated cells (figure $7 \mathrm{a}$ ). To investigate whether vitamin D induced LL-37, we assessed LL-37 expression by vitamin D treatment in control cells. At baseline, we found a significant induction of LL-37 expression with increasing concentrations of vitamin $\mathrm{D}$ in control cells compared to untreated cells $\left(10^{-8} \mathrm{M}, \mathrm{p}=0.01 ; 10^{-7} \mathrm{M}\right.$, $\mathrm{p}=0.002)$. Similarly, we reported a dose-dependent increase of LL-37 expression by $10^{-9} \mathrm{M}, 10^{-8} \mathrm{M}$ and $10^{-7} \mathrm{M}$ vitamin $\mathrm{D}$ treatment (3.2-, 166-, 539-fold induction, respectively) in RV-infected control cells compared to untreated cells ( $\mathrm{p}=0.01, \mathrm{p}=0.002, \mathrm{p}=0.002$, respectively; figure $7 \mathrm{~b}$ ).
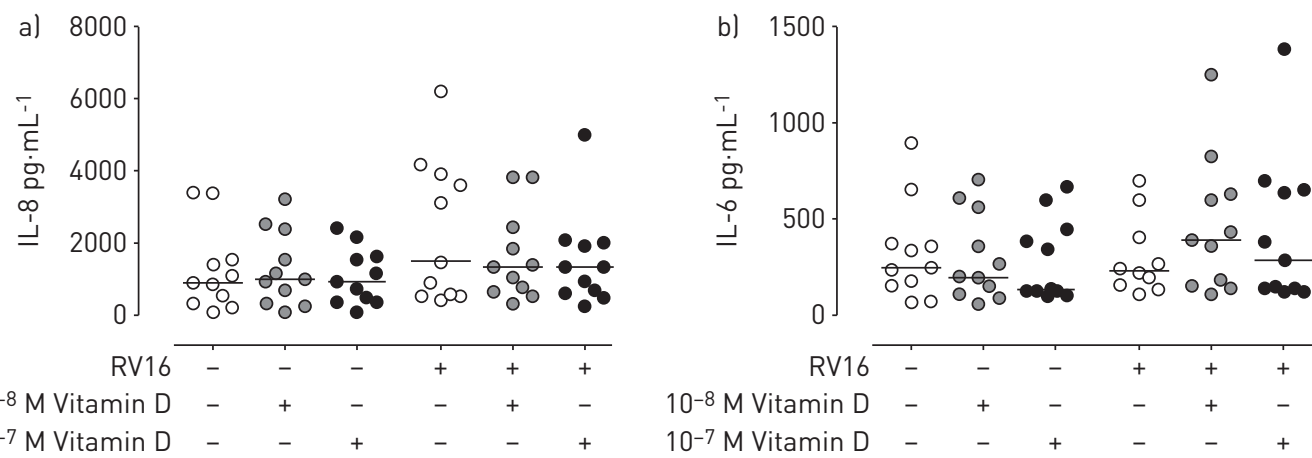

FIGURE 3 Vitamin D has no anti-inflammatory properties in rhinovirus (RV)-infected primary cystic fibrosis bronchial epithelial cells. Protein levels of interleukin (IL)-8 (a) and IL-6 (b) in cell culture supernatants were measured at $24 \mathrm{~h}$ after RV16 infection with our without vitamin $\mathrm{D}$ treatment $\left(10^{-8} \mathrm{M}\right.$ and $\left.10^{-7} \mathrm{M}\right)$ for $24 \mathrm{~h}$ by ELISA. Data are presented as median of 11 independent experiments. Statistical analysis was done with the paired non-parametric Wilcoxon rank test. 

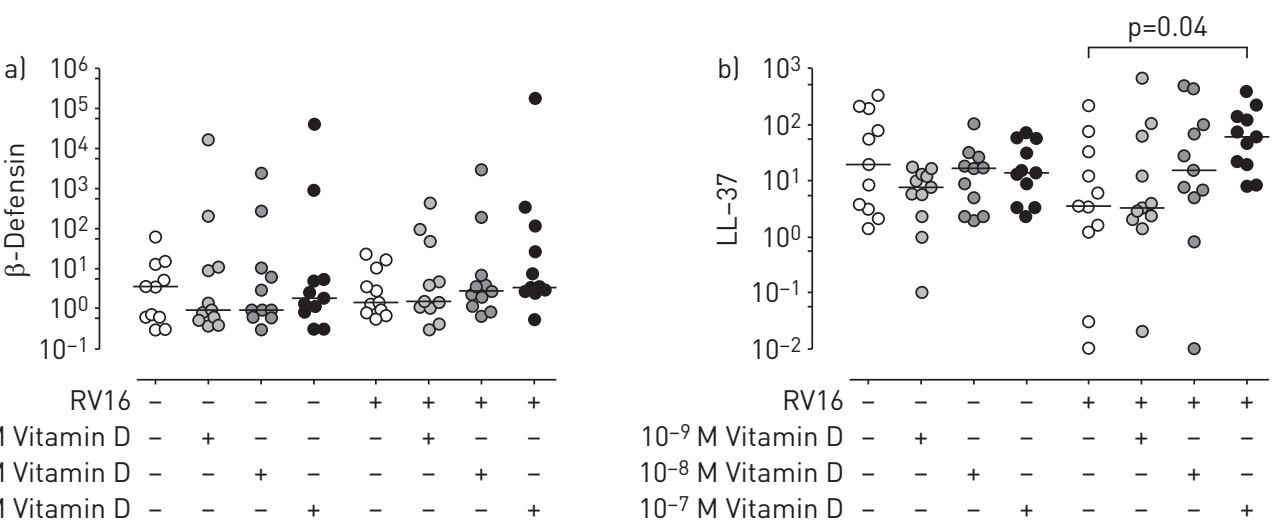

FIGURE 4 Vitamin D stimulates the expression of LL-37, but not of $\beta$-defensin in primary cystic fibrosis (CF) bronchial epithelial cells. a) $\beta$-defensin mRNA expression, normalised to $10^{7} 18 \mathrm{~S}$ mRNA, and b) LL-37 mRNA expression, normalised to $10^{5} 18 \mathrm{~S}$ mRNA, were measured at $24 \mathrm{~h}$ post rhinovirus (RV)16 infection by RT-qPCR in primary CF bronchial epithelial cells treated or not treated with Vitamin $D\left(10^{-9} \mathrm{M}, 10^{-8} \mathrm{M}\right.$ and $\left.10^{-7} \mathrm{M}\right)$ for $24 \mathrm{~h}$. Data are presented as median of 11 independent experiments. Statistical analysis was done with the paired non-parametric Wilcoxon rank test.

\section{Discussion}

Vitamin D deficiency is a common feature among CF patients and to some extent in healthy children. The aetiology of low vitamin D levels in CF arises from a combination of intestinal malabsorption, impaired metabolism and reduced exposure to sunlight [37]. Recent evidence suggests that vitamin D has important antimicrobial properties in CF [38]. However, the impact of the vitamin D status on the antiviral response in $\mathrm{CF}$ airways remains elusive. Therefore, we thoroughly investigated the influence of vitamin $\mathrm{D}$ treatment on the host antiviral response in RV-infected CF cells. This could be of relevance to CF lung disease, which is commonly exacerbated by respiratory viruses. Herein, we observed that vitamin $\mathrm{D}$ treatment reduced virus replication in CF cells, most likely by stimulating the expression of the AMP LL-37. Indeed, recombinant LL-37 treatment repressed virus replication in the CF cells. While inducing LL-37, vitamin D did not affect the antiviral response mediated by the IFNs pathway and did not exert anti-inflammatory properties on $\mathrm{RV}$-infected CF cells. These in vitro findings were supported by in vivo data, where we found an inverse correlation between RV load and LL-37 protein levels in the BALs of CF patients infected with RV.

Recent literature reported a potential role of vitamin D in the defence against virus infection including respiratory viruses such as RSV $[16,17]$ or IAV $[18,19]$. In our study, we observed that vitamin D repressed RV replication in vitro in human $\mathrm{CF}$ and control cells, further underpinning the role of vitamin $\mathrm{D}$ as modulator of the innate immune response to respiratory virus infections. In contrast to our findings,

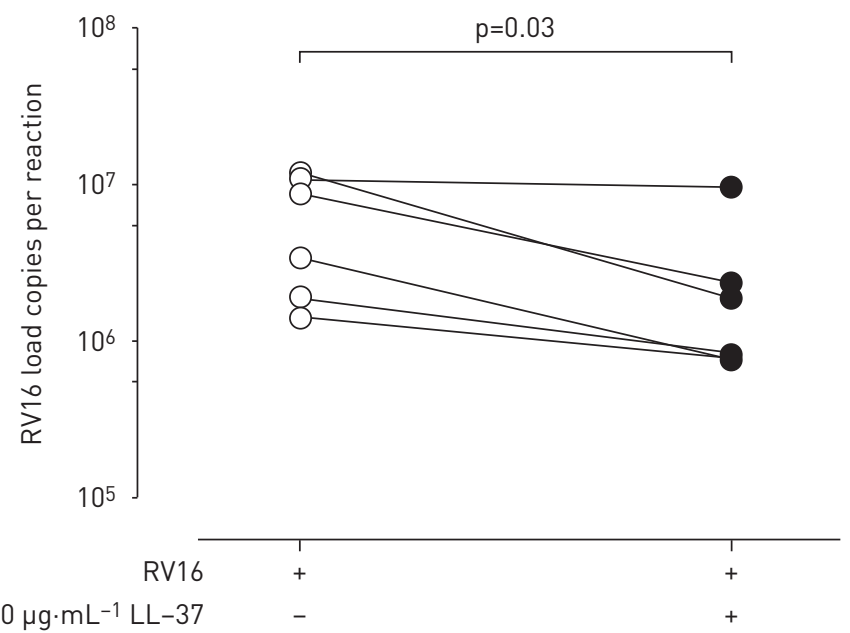

FIGURE 5 Rhinovirus (RV) load decreases by recombinant LL-37 treatment in primary cystic fibrosis (CF) bronchial epithelial cells. Intracellular viral RNA with or without $24 \mathrm{~h}$ post-treatment with recombinant LL-37 $\left(20 \mu \mathrm{g} \cdot \mathrm{mL}^{-1}\right)$ was measured at $24 \mathrm{~h}$ post RV16 infection by RT-qPCR in primary CF bronchial epithelial cells. Data are presented of six independent experiments. Statistical analysis was done with the paired non-parametric Wilcoxon rank test. 


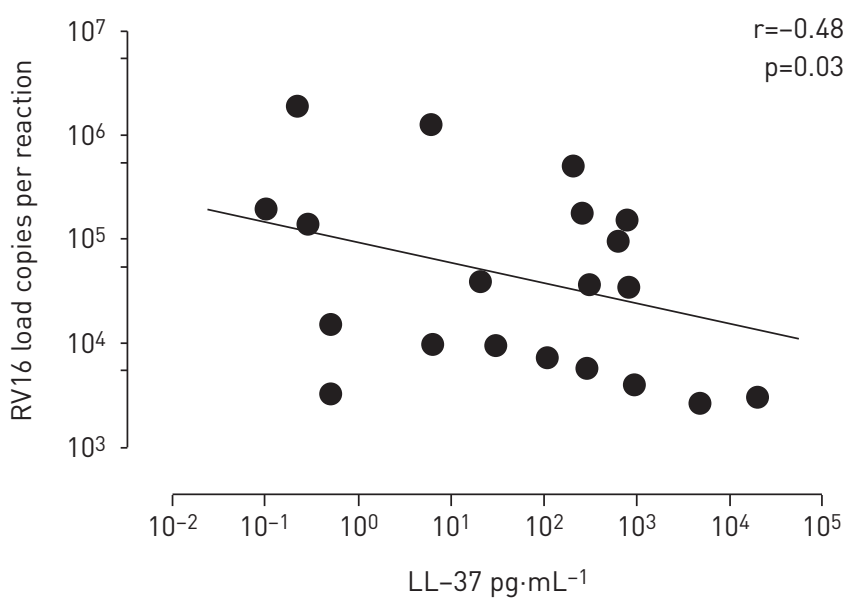

FIGURE 6 Negative correlation between rhinovirus (RV) load and LL-37 levels in bronchoalveolar lavage (BAL) of cystic fibrosis (CF) patients. RV load was assessed by RT-qPCR and LL-37 protein levels were measured by ELISA in BAL of children with CF $(n=20)$. Data are presented as scatterplot. Statistical analysis was done with the Spearman rank correlation test.

a recent study by BROCKMAN-SCHNEIDER et al. [39] found that RV replication was not reduced by vitamin D treatment in healthy human airway epithelial cells. Differences in study design (cell culture model and vitamin $\mathrm{D}$ concentrations used) might account for the discrepancy to our results.

We found that the antiviral activity of vitamin D was not associated with a stimulation of the innate immune response mediated by the IFN pathway. In accordance with our findings, the above mentioned study reported no effect of vitamin D treatment on the production of IFN- $\lambda 1$ in RV-infected human airway epithelial cells in comparison to untreated cells [39]. HANSDOTTiR et al. [4] even found a decrease in the mRNA expression of IFN- $\beta$ and the ISGs myxovirus resistance protein 1 and ISG15 by vitamin D treatment in RSV-infected human airway epithelial cells.

Surprisingly, we only observed a minor increase of inflammatory cytokine secretion by CF bronchial epithelial cells upon RV infection. This might be attributed to the fact that sampling of supernatants was performed only at $24 \mathrm{~h}$ post-infection. Thus, greater effects on cytokine secretion upon RV infection might be seen at later time points of sampling. Indeed, a recent study showed an enhanced RV-induced cytokine release by primary CF airway epithelial cells at $48 \mathrm{~h}$ after infection [40]. Further, RV16 is a less potent inducer of inflammatory cytokines compared to other RV strains such as RV1B [40].

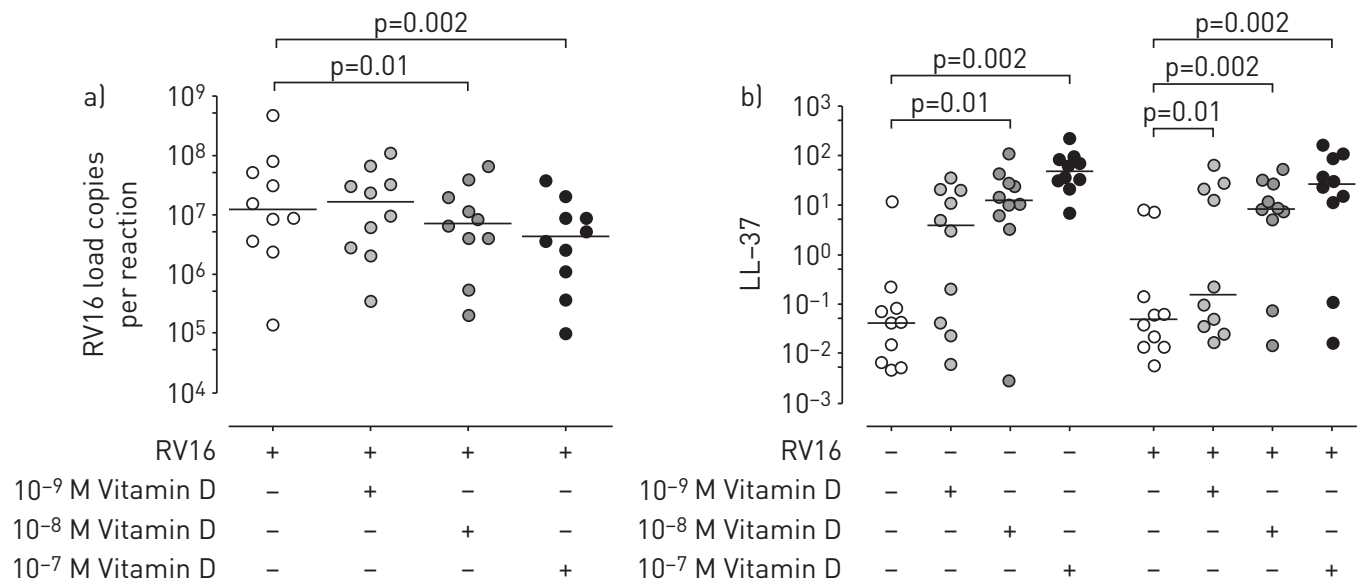

FIGURE 7 Rhinovirus (RV) load is reduced and LL-37 expression is increased by vitamin D treatment in primary healthy bronchial epithelial cells. a) Intracellular viral RNA was assessed at $24 \mathrm{~h}$ post RV16 infection by RT-qPCR in primary healthy bronchial epithelial cells treated or not treated with vitamin $D\left(10^{-9} \mathrm{M}, 10^{-8} \mathrm{M}\right.$ and $10^{-7} \mathrm{M}$ ) for $24 \mathrm{~h} \mathrm{.b)} \mathrm{LL-37} \mathrm{mRNA} \mathrm{expression,} \mathrm{normalised} \mathrm{to} 10^{5} 18 \mathrm{~S}$ mRNA, was measured at $24 \mathrm{~h}$ post RV16 infection by RT-qPCR with or without $24 \mathrm{~h}$ pre-treatment with vitamin $\mathrm{D}\left(10^{-9} \mathrm{M}, 10^{-8} \mathrm{M}\right.$ and $\left.10^{-7} \mathrm{M}\right)$ in primary healthy bronchial epithelial cells. Data are presented as median of 10 independent experiments. Statistical analysis was done with the paired non-parametric Wilcoxon rank test. 
Interestingly, in contrast to previous literature reporting anti-inflammatory properties of vitamin $\mathrm{D}$ in $\mathrm{CF}$ airway cells [38], we did not observe a reduced secretion of inflammatory cytokines by vitamin D treatment in RV-infected CF cells. A recent study even reported that the secretion of the pro-inflammatory cytokine IFN $\gamma$-induced protein 10 (IP-10) was increased by vitamin D treatment in RV-infected healthy airway epithelial cells [39]. However, an interesting study by MCNALLY et al. [30] showed that vitamin D receptor agonists decreased the release of pro-inflammatory cytokines, such as IL- 8 and IL-6, by the CF airway epithelium in response to antigen challenge. The conflicting results could be due to different pathogen challenges (Pseudomonas aeruginosa versus RV) and due to the cell culture model used [28] (cell lines versus primary cells), which might result in different inflammatory responses.

It is now well established that vitamin $\mathrm{D}$ has antimicrobial properties in vitro in CF through the induction of $\beta$-defensin and LL-37 in several cell types such as macrophages and airway epithelial cells [38]. Upon infection, the metabolism of vitamin D synergises with TLR pathway activation to induce an antimicrobial response including the induction of AMPs $[8,26]$, thus raising the possibility of locally enhanced innate immunity. The AMPs contain vitamin D-responsive elements (VDRE) in their gene promoter, whereby vitamin $\mathrm{D}$ is directly inducing LL-37 and $\beta$-defensin gene expressions [34]. Furthermore, a positive correlation between serum vitamin D levels and lung function [41] in CF patients as well as improved clinical outcomes in CF patients with pulmonary exacerbation have been demonstrated [42].

Indeed, we observed a significant induction of LL-37 but not $\beta$-defensin expression by vitamin $\mathrm{D}$ in RV-infected CF cells and also control cells in comparison to untreated cells. In our study, $\beta$-defensin expression in CF cells was barely detectable by conventional quantitative RT-PCR (Ct values $>35$ ). Remarkably, a cooperation with nuclear factor $\kappa \mathrm{B}(\mathrm{NF}-\kappa \mathrm{B})$ is required for vitamin $\mathrm{D}$-induced transcription of $\beta$-defensin. Indeed, NF- $\mathrm{BB}$ response elements adjacent to the VDRE on the promoter mediate the cooperative transcription of $\beta$-defensin [43]. In contrary, LL-37 mRNA expression is induced in a synergistic manner by calcium and vitamin D [44]. Therefore, other factors than vitamin $\mathrm{D}$ such as inflammatory cytokines or calcium regulate the transcription of LL-37 and $\beta$-defensin, which might explain why LL-37 but not $\beta$-defensin expression was induced upon vitamin $\mathrm{D}$ in the CF cells. Interestingly, LL-37 has been shown to have antiviral properties against respiratory viruses [35] suggesting that LL-37 might be involved in the regulation of the antimicrobial host response through direct induction by vitamin $\mathrm{D}$. In accordance, we found that treatment of RV-infected CF cells with recombinant LL-37 significantly reduced virus replication compared to untreated CF cells. Experimental evidences suggest that LL-37 mediates its antiviral properties by disrupting and damaging the viral envelope of viruses such as IVA and vaccinia virus, whereas the mode of action on non-enveloped viruses such as RVs is still unclear and needs further investigation [35].

Interestingly, we observed a negative association between RV load and LL-37 protein levels in BALs of CF patients infected with RV, suggesting that CF patients with lower levels of LL-37 might be more susceptible for pulmonary RV infection. It would be interesting to assess LL-37 levels in RV-positive BALs of healthy children, which however was not possible due to the difficulties to obtain such samples.

Moreover, healthy children are often presented with insufficient levels of serum vitamin D, especially during winter time when sun exposure is reduced [36]. We found diminished viral replication in healthy bronchial cells after vitamin D treatment, which might be associated with an increased expression of LL-37 by vitamin $\mathrm{D}$. These findings suggest that the antiviral properties of vitamin $\mathrm{D}$ are independent of the health status of the airways. Remarkably, we observed higher expression of LL-37 in CF cells compared with control cells. This however might be due to the fact that LL-37 is a marker for bronchial inflammation, which is pronounced in CF lung disease [45].

The following limitations should be considered when interpreting our results. We have used a cell culture model based on submerged cell cultures, which are not fully differentiated. Thus it would be interesting to repeat our experiments in a more physiological model of fully differentiated airway epithelial cultures grown at the air-liquid interface. Further, interaction between bacteria and respiratory viruses were not taken into account in the study. Moreover, we did not perform any nasal swabbing to exclude ongoing infection in the upper airways. A major limitation of the study was that vitamin D levels assessed in BALs of children with CF were below detection limit $\left(11 \mathrm{ng} \cdot \mathrm{mL}^{-1}\right)$ as measured by a commercially available ELISA kit (data not shown) and serum vitamin D values of the CF children at the time of bronchoscopy were not available.

In conclusion, we report a repressive effect of vitamin D on RV replication in primary bronchial epithelial cells of CF and healthy children, possibly associated with the induction of the AMP LL-37, of which we demonstrated antiviral properties against RV infection in CF cells. LL-37 protein in BALs of CF children is inversely associated with RV load, which sheds light on the importance of LL-37 in the defence against respiratory viruses. Our data suggest that vitamin D may be a modulator of the antiviral response in $\mathrm{CF}$ 
patients and point to the importance of adequate control of the vitamin D in patients suffering from CF. Clinical studies are needed to investigate the role of vitamin $\mathrm{D}$ in the prevention of virus-associated pulmonary deteriorations in CF.

\section{Acknowledgements}

The authors would like to thank all study participants and their families. This study has been supported by a financial grant from the Mukoviszidose Institut gGmbH, Bonn, Germany, the research and development arm of the German Cystic Fibrosis Association Mukoviszidose e.V, Bonn, Germany.

\section{References}

1 Asner S, Waters V, Solomon M, et al. Role of respiratory viruses in pulmonary exacerbations in children with cystic fibrosis. J Cyst Fibros 2012; 11: 433-439.

2 Wat D, Gelder C, Hibbitts S, et al. The role of respiratory viruses in cystic fibrosis. J Cyst Fibros 2008; 7: 320-328.

3 Wark PA, Tooze M, Cheese L, et al. Viral infections trigger exacerbations of cystic fibrosis in adults and children. Eur Respir J 2012; 40: 510-512.

4 Hansdottir S, Monick MM, Lovan N, et al. Vitamin D decreases respiratory syncytial virus induction of NF-kappaB-linked chemokines and cytokines in airway epithelium while maintaining the antiviral state. J Immunol 2010; 184: 965-974.

5 de Almeida MB, Zerbinati RM, Tateno AF, et al. Rhinovirus $\mathrm{C}$ and respiratory exacerbations in children with cystic fibrosis. Emerg Infect Dis 2010; 16: 996-999.

6 Flight WG, Bright-Thomas RJ, Tilston P, et al. Incidence and clinical impact of respiratory viruses in adults with cystic fibrosis. Thorax 2014; 69: 247-253.

7 Tang AC, Turvey SE, Alves MP, et al. Current concepts: host-pathogen interactions in cystic fibrosis airways disease. Eur Respir Rev 2014; 23: 320-332.

8 Hansdottir S, Monick MM, Hinde SL, et al. Respiratory epithelial cells convert inactive vitamin D to its active form: potential effects on host defense. J Immunol 2008; 181: 7090-7099.

9 Di Rosa M, Malaguarnera M, Nicoletti F, et al. Vitamin D3: a helpful immuno-modulator. Immunology 2011; 134: 123-139.

10 Rovner AJ, Stallings VA, Schall JI, et al. Vitamin D insufficiency in children, adolescents, and young adults with cystic fibrosis despite routine oral supplementation. Am J Clin Nutr 2007; 86: 1694-1699.

11 Boyle MP, Noschese ML, Watts SL, et al. Failure of high-dose ergocalciferol to correct vitamin D deficiency in adults with cystic fibrosis. Am J Respir Crit Care Med 2005; 172: 212-217.

12 Science M, Maguire JL, Russell ML, et al. Low serum 25-hydroxyvitamin D level and risk of upper respiratory tract infection in children and adolescents. Clin Infect Dis 2013; 57: 392-397.

13 Ginde AA, Mansbach JM, Camargo CA, Jr. Association between serum 25-hydroxyvitamin D level and upper respiratory tract infection in the Third National Health and Nutrition Examination Survey. Arch Intern Med 2009; 169: 384-390.

14 Roth DE, Shah R, Black RE, et al. Vitamin D status and acute lower respiratory infection in early childhood in Sylhet, Bangladesh. Acta Paediatr 2010; 99: 389-393.

15 Wayse V, Yousafzai A, Mogale K, et al. Association of subclinical vitamin D deficiency with severe acute lower respiratory infection in Indian children under 5 y. Eur J Clin Nutr 2004; 58: 563-567.

16 Stoppelenburg AJ, von Hegedus JH, Huis in't Veld R, et al. Defective control of vitamin D receptor-mediated epithelial STAT1 signalling predisposes to severe respiratory syncytial virus bronchiolitis. J Pathol 2014; 232: $57-64$.

17 Janssen R, Bont L, Siezen CL, et al. Genetic susceptibility to respiratory syncytial virus bronchiolitis is predominantly associated with innate immune genes. J Infect Dis 2007; 196: 826-834.

18 Urashima M, Segawa T, Okazaki M, et al. Randomized trial of vitamin D supplementation to prevent seasonal influenza A in schoolchildren. Am J Clin Nutr 2010; 91: 1255-1260.

19 Cannell JJ, Vieth R, Umhau JC, et al. Epidemic influenza and vitamin D. Epidemiol Infect 2006; 134: 1129-1140.

20 Kieninger E, Singer F, Tapparel C, et al. High rhinovirus burden in lower airways of children with cystic fibrosis. Chest 2013; 143: 782-790.

21 Schogler A, Kopf BS, Edwards MR, et al. Novel antiviral properties of azithromycin in cystic fibrosis airway epithelial cells. Eur Respir J 2015; 45: 428-439.

22 Papi A, Johnston SL. Rhinovirus infection induces expression of its own receptor intercellular adhesion molecule 1 (ICAM-1) via increased NF-kappaB-mediated transcription. I Biol Chem 1999; 274: 9707-9720.

23 Intrieri $\mathrm{M}$, Rinaldi $\mathrm{A}$, Scudiero $\mathrm{O}$, et al. Low expression of human beta-defensin 1 in duodenum of celiac patients is partially restored by a gluten-free diet. Clin Chem Lab Med 2010; 48: 489-492.

24 Gombart AF, Borregaard N, Koeffler HP. Human cathelicidin antimicrobial peptide (CAMP) gene is a direct target of the vitamin $\mathrm{D}$ receptor and is strongly up-regulated in myeloid cells by 1,25 -dihydroxyvitamin D3. FASEB J 2005; 19: 1067-1077.

25 Currie SM, Findlay EG, McHugh BJ, et al. The human cathelicidin LL-37 has antiviral activity against respiratory syncytial virus. PLoS One 2013; 8: e73659.

26 Liu PT, Stenger S, Li H, et al. Toll-like receptor triggering of a vitamin D-mediated human antimicrobial response. Science 2006; 311: 1770-1773.

27 Slater L, Bartlett NW, Haas JJ, et al. Co-ordinated role of TLR3, RIG-I and MDA5 in the innate response to rhinovirus in bronchial epithelium. PLoS Pathog 2010; 6: e1001178.

28 Sutanto EN, Kicic A, Foo CJ, et al. Innate inflammatory responses of pediatric cystic fibrosis airway epithelial cells: effects of nonviral and viral stimulation. Am J Respir Cell Mol Biol 2011; 44: 761-767.

29 Ribeiro CM, Paradiso AM, Schwab U, et al. Chronic airway infection/inflammation induces a Ca2+i-dependent hyperinflammatory response in human cystic fibrosis airway epithelia. J Biol Chem 2005; 280: 17798-17806.

30 McNally P, Coughlan C, Bergsson G, et al. Vitamin D receptor agonists inhibit pro-inflammatory cytokine production from the respiratory epithelium in cystic fibrosis. J Cyst Fibros 2011; 10: 428-434.

31 Zasloff M. Antimicrobial peptides of multicellular organisms. Nature 2002; 415: 389-395. 
32 Bals R, Hiemstra PS. Innate immunity in the lung: how epithelial cells fight against respiratory pathogens. Eur Respir J 2004; 23: 327-333.

33 Yim S, Dhawan P, Ragunath C, et al. Induction of cathelicidin in normal and CF bronchial epithelial cells by 1,25-dihydroxyvitamin D(3). J Cyst Fibros 2007; 6: 403-410.

34 Wang TT, Nestel FP, Bourdeau V, et al. Cutting edge: 1,25-dihydroxyvitamin D3 is a direct inducer of antimicrobial peptide gene expression. J Immunol 2004; 173: 2909-2912.

35 Gwyer Findlay E, Currie SM, Davidson DJ. Cationic host defence peptides: potential as antiviral therapeutics. BioDrugs 2013; 27: 479-493.

36 Gordon CM, Feldman HA, Sinclair L, et al. Prevalence of vitamin D deficiency among healthy infants and toddlers. Arch Pediatr Adolesc Med 2008; 162: 505-512.

37 Sermet-Gaudelus I, Castanet M, Retsch-Bogart G, et al. Update on cystic fibrosis-related bone disease: a special focus on children. Paediatr Respir Rev 2009; 10: 134-142.

38 Herscovitch K, Dauletbaev N, Lands LC. Vitamin D as an anti-microbial and anti-inflammatory therapy for Cystic Fibrosis. Paediatr Respir Rev 2014; 15: 154-162.

39 Brockman-Schneider RA, Pickles RJ, Gern JE. Effects of vitamin D on airway epithelial cell morphology and rhinovirus replication. PLoS One 2014; 9: e86755.

40 Kieninger E, Vareille M, Kopf BS, et al. Lack of an exaggerated inflammatory response on virus infection in cystic fibrosis. Eur Respir J 2012; 39: 297-304.

41 Sexauer WP, Hadeh A, Ohman-Strickland PA, et al. Vitamin D deficiency is associated with pulmonary dysfunction in cystic fibrosis. J Cyst Fibros 2015; 14: 497-506.

42 Grossmann RE, Zughaier SM, Kumari M, et al. Pilot study of vitamin D supplementation in adults with cystic fibrosis pulmonary exacerbation: A randomized, controlled trial. Dermatoendocrinol 2012; 4: 191-197.

43 Kao CY, Kim C, Huang F, et al. Requirements for two proximal NF-kappaB binding sites and IkappaB-zeta in IL-17A-induced human beta-defensin 2 expression by conducting airway epithelium. J Biol Chem 2008; 283: 15309-15318.

44 Weber G, Heilborn JD, Chamorro Jimenez CI, et al. Vitamin D induces the antimicrobial protein hCAP18 in human skin. J Invest Dermatol 2005; 124: 1080-1082.

45 Chen CI, Schaller-Bals S, Paul KP, et al. Beta-defensins and LL-37 in bronchoalveolar lavage fluid of patients with cystic fibrosis. J Cyst Fibros 2004; 3: 45-50. 